\title{
DDX52 wt Allele
}

National Cancer Institute

\section{Source}

National Cancer Institute. DDX52 wt Allele. NCI Thesaurus. Code C106434.

Human DDX52 wild-type allele is located in the vicinity of 17q21.1 and is approximately 34 $\mathrm{kb}$ in length. This allele, which encodes probable AT P-dependent RNA helicase DDX52 protein, is involved in both ATP hydrolysis and RNA binding. 